\title{
Deteksi filariasis dan vektornya di wilayah kerja Dinas Kesehatan Kabupaten Bantul, Daerah Istimewa Yogyakarta
}

\author{
Budi Mulyaningsih, ${ }^{1 *}$ Sitti Rahmah Umniyati, ${ }^{1}$ Ernaningsih, ${ }^{1}$ Tri Baskoro Tunggul Satoto, ${ }^{1}$ \\ Tridjoko Hadianto, ${ }^{1}$ dan Siti Isti'anah ${ }^{2}$ \\ ${ }^{1}$ Departemen Parasitologi, Fakultas Kedokteran, Kesehatan Masyarakat, dan Keperawatan, \\ Universitas Gadjah Mada, Yogyakarta, Indonesia \\ ${ }^{2}$ Departemen Parasitologi, Fakultas Kedokteran, Universitas Islam Indonesia, Yogyakarta, Indonesia
}

Submitted: 3 Desember 2018 Revised: 19 Desember 2019 Accepted: 21 Desember 2019

\begin{abstract}
ABSTRAK Di wilayah kerja Dinas Kesehatan Kabupaten Bantul, Daerah Istimewa Yogyakarta telah dilaporkan 6 orang penderita elefantiasis dan diduga sebagai penderita filariasis. Elefantiasis digolongkan menjadi dua, yaitu elefantiasis filaria dan elefantiasis nonfilaria. Elefantiasis filaria dis,ebabkan oleh infeksi cacing filarial limfatik, sedangkan elefantiasis nonfilaria antara lain disebabkan oleh podokoniosis, lepra, tuberkulosis, dan infeksi chlamydia. Tujuan dari program ini adalah untuk memastikan apakah penderita elefantiasis tersebut disebabkan oleh filariasis. Kegiatan dilaksanakan di wilayah kerja Dinas Kesehatan Kabupaten Bantul pada bulan Juli 2016 dengan cara: (1) survei lokasi penderita, (2) wawancara dengan penderita, keluarganya, dan masyarakat sekitarnya, (3) pemeriksaan penderita, dan (4) survei lingkungan sekitar tempat tinggal penderita untuk memastikan ada tidaknya tempat perindukan (breeding place) nyamuk vektornya. Dari kegiatan ini ditemukan dua orang penderita elefantiasis. Penderita dari Dusun Depok, Kelurahan Gilangharjo, Kecamatan Pandak diduga menderita elefantiasis karena infeksi cacing filaria Brugia malayi. Penderita dari Dusun Cawan, Kelurahan Argodadi, Kecamatan Sedayu diduga menderita elefantiasis yang diakibatkan oleh podoconiosis. Di Dusun Cawan, banyak ditemukan tempat perindukan nyamuk Anopheles vagus.
\end{abstract}

KATA KUNCI Anopheles vagus; Brugia malayi; elefantiasis; filariasis; podoconiosis

ABSTRACT In Bantul, Yogyakarta Special Region there have been reported 6 elephantiasis cases and ware suspected as filariasis. Elephantiasis is classified into two, namely filarial elephantiasis and nonfilarial elephantiasis. Filarial elephantiasis caused by lymphatic filarial worms infection while, nonfilarial elephantiasis can be caused by podoconiosis, leprosy, tuberculosis, or chlamydia infection. The aim of the study was to ascertain whether elephantiasis cases are caused by filariasis. Activities carried out in the work area of the Bantul District Health Office in July 2016 i.e.: (1) patient location survey, (2) interviews with patients, their families, and surrounding communities, (3) examination of patients, and (4) observe the environment around the patient's residence to ensure existence of vector mosquito breeding places. This study found two people with elephantiasis, patients from Depok, Gilangharjo, Pandak, Bantul was suspected elephantiasis due to Brugia malayi infection. Patient from Cawan, Argodadi, Sedayu, Bantul was suspected elephantiasis due to podoconiosis. In Cawan found many breeding sites for the Anopheles vagus mosquito.

KEYWORDS Anopheles vagus; Brugia malayi; elephantiasis; filariasis; podoconiosis

\footnotetext{
*Corresponding author: Budi Mulyaningsih

Departemen Parasitologi, Fakultas Kedokteran Kesehatan Masyarakat dan Keperawatan, Universitas Gadjah Mada, Jl. Farmako, Sekip Utara, Yogyakarta 55281, Indonesia

Email: budi.mulyaningsih@ugm.ac.id
} 


\section{Pendahuluan}

Filariasis adalah penyakit menular dan menahun yang disebabkan oleh infeksi cacing filaria limfatik dan filaria nonlimfatik yang ditularkan melalui gigitan berbagai spesies vektornya. Filariasis limfatik terdapat di seluruh dunia terutama di daerah tropis dan beberapa daerah subtropis. Pada tahun 2004 diperkirakan 120 juta orang menderita filariasis di 73 negara endemik filariasis dengan perkiraan 1,3 milyar orang yang berada di daerah transmisi filariasis. ${ }^{1}$

Filariasis merupakan neglected disease, yaitu penyakit yang terabaikan dan pertama kali ditemukan di Indonesia pada tahun 1877. ${ }^{2}$ Penyakit ini tersebar luas hampir di seluruh provinsi di Indonesia. Secara nasional dalam kurun waktu 10 - 12 tahun menunjukkan peningkatan kasus dan penderita yang cukup signifikan, yaitu dari sekitar 6.500 kasus di tahun 2002 meningkat menjadi 12.066 kasus di tahun 2011, bahkan menjadi 14.932 di tahun 2014. ${ }^{3}$ Transmisi parasit di beberapa daerah endemis masih saja terjadi. Hal ini diketahui dengan ditemukannya kasus filariasis klinis baru setiap tahunnya.

Cacing filaria penyebab filariasis limfatik di Indonesia ada 3 spesies, yaitu Wuchereria bancrofti, Brugia malayi, dan Brugia timori, sedangkan berdasarkan epidemiologinya dilaporkan terdapat 6 spesies, yaitu $W$. bancrofti tipe perkotaan dan $W$. bancrofti tipe pedesaan yang bersifat periodik nokturnal, $B$. malayi periodik nocturnal, B. malayi subperiodik nokturnal, B. malayi non periodic, dan B. timori periodik nokturnal. ${ }^{4}$ Filariasis di Indonesia sebagian besar disebabkan oleh cacing $B$. malayi. ${ }^{5}$ Filariasis $W$. bancrofti banyak ditemukan di Pulau Jawa, Bali, Nusa Tenggara Barat, dan Papua sedangkan filariasis $B$. timori hanya ditemukan di Indonesia bagian timur yaitu di Pulau Timor, Flores, Rote, Alor, dan beberapa pulau kecil di Nusa Tenggara Timur (NTT). ${ }^{6}$

Manusia dapat terinfeksi jika nyamuk yang mengandung larva cacing filarial stadium $3\left(\mathrm{~L}_{3}\right)$ menghisap darah, selanjutnya $L_{3}$ ikut aliran darah menuju ke saluran limfa, kemudian berubah bentuk dan berkembang menjadi $L_{4}, L_{5}$ (dewasa muda), dan dewasa. Setelah terjadi perkawinan antara cacing jantan dan betina lahirlah mikrofilaria yang menuju ke darah tepi pada waktu malam hari atau siang hari sesuai periodisitasnya. Di luar waktu tersebut, mikrofilaria akan bersembunyi di pembuluh kapiler organ dalam. Mikrofilaria ini kemudian akan mengikuti siklus nyamuk jika terdapat nyamuk vektor yang menggigit. Di dalam tubuh nyamuk, mikrofilaria tersebut berkembang menjadi $L_{1}, L_{2}$, dan $L_{3}$ yang siap diinfeksikan ke dalam tubuh manusia. ${ }^{7,8}$ Cacing filaria dewasa di dalam tubuh inang mampu hidup selama 5 - 10 tahun kadang-kadang dapat mencapai 40 tahun. Sedangkan stadium mikrofilaria di dalam darah hanya mampu hidup sekitar 70 hari, artinya jika mikrofilaria tesebut tidak dihisap nyamuk, akan segera mati. Mikrofilaria di dalam inang perantara (nyamuk) akan berubah bentuk dan berkembang menjadi larva stadium 3 (L3) dalam waktu kurang-lebih 14 hari. Larva stadium 3 merupakan bentuk infektifnya, artinya jika nyamuk yang mengandung larva tersebut menggigit manusia dapat menyebabkan terjadinya infeksi cacing filaria. ${ }^{9,10} \mathrm{Di}$ Indonesia, vektor penular filariasis yang telah diketahui ada 23 spesies nyamuk dari genus Anopheles, Culex, Mansonia, Aedes, dan Armigeres. ${ }^{11}$

Gambaran klinis filariasis sangat bervariasi tergantung dengan respon imun masing-masing penderita. Patogenesis dapat disebabkan oleh parasitnya sendiri (stadium larva, dewasa, dan mikrofilaria) atau respon imun yang berlebihan dari inang. Di dalam tubuh inang, parasit akan mengeluarkan antigen ekskretori-sekretori yang akan memacu timbulnya radang. Cacing dewasa yang masih hidup maupun yang telah mati akan memicu tejadinya sumbatan (obstruksi) sistem limfatik sehingga terjadi pembengkakan (elefantiasis) yang terus berjalan sampai bertahun tahun, dan terjadi secara retrogradasi, yaitu dengan terjadinya limfangitis descenden yang berlanjut menjadi limfadema. ${ }^{8,12}$ Filariasis dapat menimbulkan cacat menetap berupa pembesaran 
kaki, tangan, dan organ kelamin. Penyakit ini tidak menyebabkan kematian secara langsung tetapi terjadi secara menahun dan bersifat irreversible. ${ }^{13}$

Berdasarkan informasi yang berasal dari Dinas Kesehatan Kabupaten Bantul, Daerah Istimewa Yogyakarta (DIY) terdapat enam orang yang kakinya mengalami pembesaran (elefantiasis) dan diduga sebagai penderita filariasis di wilayah kerjanya. Untuk menindaklanjuti informasi tersebut, maka dilakukan penelitian terhadap penderita elefantiasis dengan melakukan pemeriksaan fisik dan laboratorium, serta survei habitat nyamuk di sekitar tempat tinggal penderita yang dapat berperan sebagai vektor filariasis. Penelitian ini penting dilakukan untuk mengetahui: (1) apakah elefantiasis tersebut akibat filariasis, (2) persebaran tempat tinggal penderita elefantiasis, (3) bagaimana status kependudukan penderita elefantiasis, penduduk asli atau pendatang, (4) bagaimana lingkungan tempat tinggalnya, apakah cocok sebagai tempat perindukan (breeding place) nyamuk vektor filariasis, sebagai antisipasi terjadinya penularan kepada masyarakat di sekitarnya.

\section{Metode}

Desain penelitian ini adalah cross-sectional menggunakan data sekunder dari Kegiatan Pengabdian Masyarakat dengan Dana Masyarakat tahun 2016 yang dilakukan oleh staf Departemen Parasitologi, Fakultas Kedokteran, Kesehatan Masyarakat, dan Keperawatan (FK-KMK), Universitas Gadjah Mada (UGM) bekerja sama dengan Dinas Kesehatan Kabupaten Bantul pada tanggal 12 - 14 Juli 2016. Kegiatan dilakukan di dua pusat kesehatan masyarakat (puskesmas) yaitu Puskesmas Sedayu 2 di Dusun Cawan, Kelurahan Argodadi, Kecamatan Sedayu, Kabupaten Bantul, DIY dan Puskesmas Pandak 1 yang di wilayahnya terdapat penderita elefantiasis, yaitu di Dusun Depok, Kelurahan Gilangharjo, Kecamatan Pandak Kabupaten Bantul, DIY. Penulisan hasil penelitian ini sudah mendapat persetujuan dari Komisi Etik FKKMK UGM dengan No. KE/FK/0389/EC/201.

Penelitian ini dilakukan dengan cara: (1) survei lokasi dan wawancara dengan penderita, keluarga penderita dan masyarakat sekitarnya, (2) pemeriksaan fisik penderita, (3) survei lingkungan sekitar tempat tinggal penderita untuk memastikan ada tidaknya tempat perindukan (breeding place) nyamuk yang dapat berperan sebagai vektor cacing filaria limfatik. Survei nyamuk di sekitar tempat tinggal penderita di Dusun Cawan dilakukan dengan penelusuran lubang-lubang yang ada di tepi Sungai Progo. Survei nyamuk di sekitar tempat tinggal penderita di Dusun Depok dilakukan di rumah penderita dan lingkungan sekitarnya. Identifikasi nyamuk dilakukan menurut cara dari Stojanovich dan Scoot. ${ }^{14}$

\section{Hasi}

\subsection{Gambaran umum masyarakat sasaran}

Luas wilayah Kabupaten Bantul 508,9 km² (15,9 \% dari luas wilayah Provinsi DIY) dengan topografi dataran rendah $40,0 \%$ dan lebih dari separuhnya $(60,0 \%)$ merupakan daerah perbukitan yang kurang subur. Jumlah penduduk Bantul pada tahun 2013 adalah 1.015.465 jiwa dengan kepadatan $2.012,9 \mathrm{jiwa} / \mathrm{km}^{2}$. Kecamatan dengan jumlah penduduk terbanyak dan terpadat di Kabupaten Bantul adalah Kecamatan Banguntapan dengan jumlah penduduk 120.123 jiwa dengan kepadatan $4.218,0 \mathrm{jiwa} / \mathrm{km}^{2}$. Mayoritas mata pencaharian penduduk Bantul adalah di bidang pertanian $(25,0 \%)$, perdagangan $(21,0 \%)$, industri $(19,0 \%)$, dan jasa $(17,0 \%)$. Kabupaten Bantul terdiri atas tujuh belas kecamatan, dua di antaranya adalah Kecamatan Pandak dan Kecamatan Sedayu, dan di dua kecamatan tersebut diduga terdapat penderita filariasis. ${ }^{15}$

\subsection{Lokasi tempat tinggal penderita elefantiasis di wilayah kerja Dinas Kesehatan Kabupaten Bantul, DIY}

Menurut laporan dari Dinas Kesehatan Kabupaten Bantul DIY, di wilayah kerjanya dijumpai sekitar enam orang yang mengalami pembesaran kaki (elefantiasis) dan diduga sebagai penderita filariasis. Setelah ditelusuri hanya ditemukan dua orang penderita, yaitu seorang penderita yang berada di 
Tabel 1. Keberadaan penderita elefantiasis di wilayah kerja Dinas Kesehatan Kabupaten Bantul, DIY

\begin{tabular}{cccc}
\hline $\begin{array}{c}\text { Wilayah kerja Dinkes Kab. } \\
\text { Bantul DIY }\end{array}$ & $\begin{array}{c}\text { Tidak ditemukan } \\
\text { alamatnya }\end{array}$ & Puskesmas & Puskesmas \\
Pandak 1 & Sedayu 2 \\
\hline 6 penderita & 4 penderita & 1 penderita & 1 penderita \\
& $(66,7 \%)$ & $(16,7 \%)$ & $(16,7 \%)$ \\
\hline
\end{tabular}

Tabel 2. Riwayat hidup penderita elefantiasis di wilayah kerja Dinas Kesehatan Kabupaten Bantul DIY

\begin{tabular}{lcc}
\hline \multicolumn{1}{c}{ Riwayat } & $\begin{array}{c}\text { Penderita dari } \\
\text { Dusun Depok }\end{array}$ & $\begin{array}{c}\text { Penderita dari } \\
\text { Dusun Cawan }\end{array}$ \\
\hline Jenis kelamin & Laki-laki & Laki-laki \\
Umur & 40 tahun & 37 tahun \\
Pendidikan & SMP & SD \\
Pekerjaan & Petani & Petani \\
Pernah tinggal di luar daerah Bantul & Lampung (selama \pm 6 tahun) & Tidak pernah \\
\hline
\end{tabular}

Dusun Depok, Kelurahan Gilangharjo, Kecamatan Pandak yang termasuk dalam wilayah kerja Puskesmas Pandak 1 dan seorang penderita lainnya yang berada di Dusun Cawan, Kelurahan Argodadi, Kecamatan Sedayu yang termasuk dalam wilayah kerja Puskesmas Sedayu 2. Empat penderita yang lain tidak dapat ditemukan karena alamatnya tidak jelas, sehingga tidak bisa dilacak keberadaannya. Pencacatan alamat penderita suatu penyakit di puskesmas sangat penting untuk menindaklanjuti perkembangan penyakit yang diderita. Hal tersebut diperlukan, baik untuk kepentingan penderita maupun untuk kepentingan dinas kesehatan dalam menanggulangi suatu penyakit di suatu daerah

\subsection{Asal penderita elefantiasis}

Penderita elefantiasis yang berada di wilayah kerja Puskesmas Pandak 1 bertempat tinggal di Dusun Depok, Kelurahan Gilangharjo, Kecamatan Pandak, Kabupaten Bantul, DIY. Sedangkan penderita yang berada di wilayah kerja Puskesmas Sedayu 2 bertempat tinggal di Dusun Cawan, Kelurahan Argodadi, Kecamatan Sedayu, Kabupaten Bantul, DIY.

\subsection{Pemeriksaan fisik penderita elefantiasis}

Berdasarkan informasi yang diperoleh dari petugas dinas kesehatan, kedua orang tersebut sudah pernah diperiksa darahnya untuk memastikan keberadaan mikrofilaria dan hasilnya negatif. Dari hasil pemeriksaan fisik penderita di Dusun Depok, terlihat sudah terjadi pembesaran tungkai bawah kiri yang dimulai dari lutut. Pada perabaan sudah terjadi pengerasan (fibrosis) pada bagian yang membesar tersebut (Gambar 1). Pada penderita sudah pernah dilakukan pemeriksaan darah untuk pemeriksaan filariasis dan hasilnya negatif, artinya tidak ditemukan mikrofilaria dalam darah penderita.

Pada penderita dari Dusun Cawan, awalnya terdapat benjolan di telapak kaki kirinya, benjolan tersebut semakin lama semakin membesar dan menjalar ke atas (asenden). Penderita ini sudah pernah berobat ke Rumah Sakit Umum Pusat Dr. Sardjito, dan sudah pernah dioperasi 2 kali, namun kondisinyatidak berubah, bahkan dirasakan semakin membesar (Gambar 2). Dari hasil pemeriksaan fisik diketahui bahwa sudah terjadi pembengkakan tungkai bawah kiri. Pada perabaan tidak terjadi pengerasan (fibrosis) pada bagian yang membesar tersebut. Jaringan di sekitar pembengkakan lunak. Apabila bagian yang membesar tersebut diletakan dengan posisi di atas maka pembengkakannya akan berkurang (mengecil). Pada saat dilakukan pemeriksaan tidak ada keluhan-keluhan lain yang berarti. 


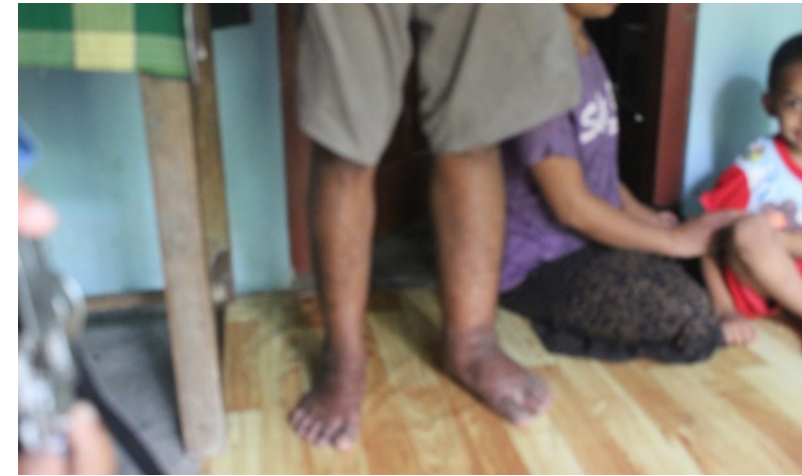

Gambar 1. Pembengkakan tungkai bawah kiri pada penderita elefantiasis di Dusun Depok, Gilangharjo, Pandak, Bantul, DIY

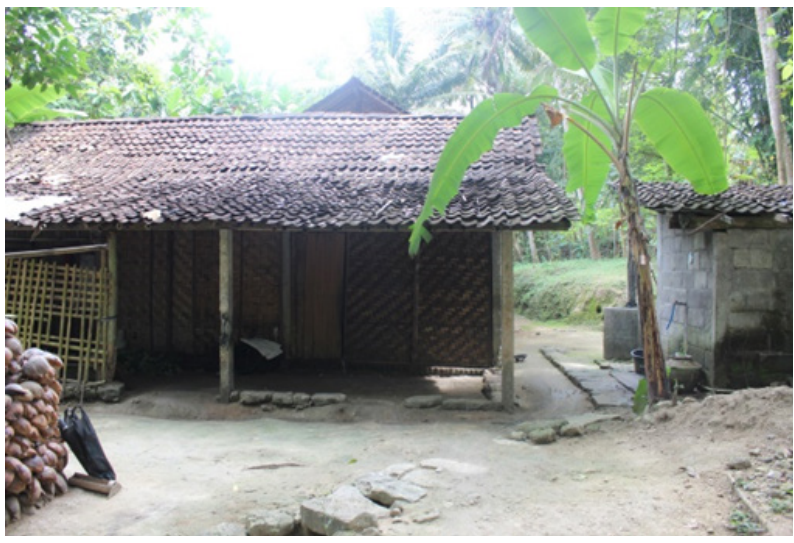

Gambar 3 (a). Lingkungan di sekitar tempat tinggal penderita filariasis di Dusun Depok, Gilangharjo, Pandak, Bantul, DIY

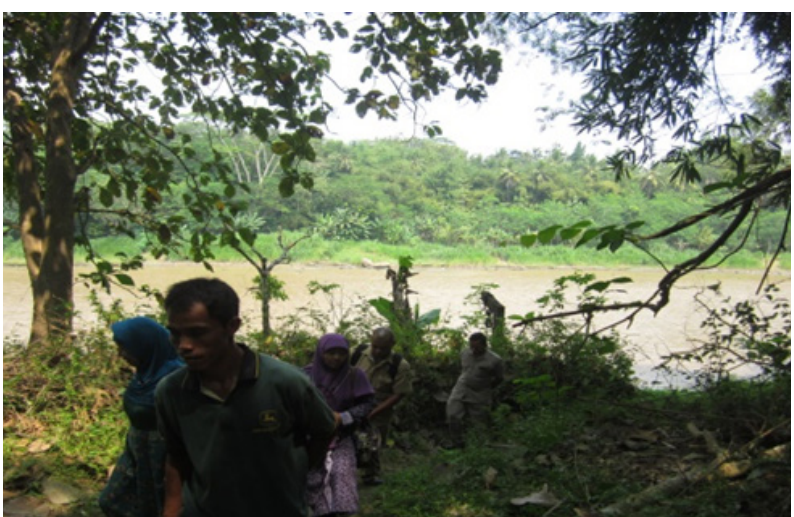

Gambar 4. Lingkungan di sekitar tempat tinggal penderita filariasis di Dusun Cawan, Argodadi, Sedayu Bantul, DIY

\subsection{Survei lingkungan}

Survei lingkungan di sekitar tempat tinggal penderita elefantiasis dilakukan untuk memastikan ada atau tidaknya tempat yang memungkinkan

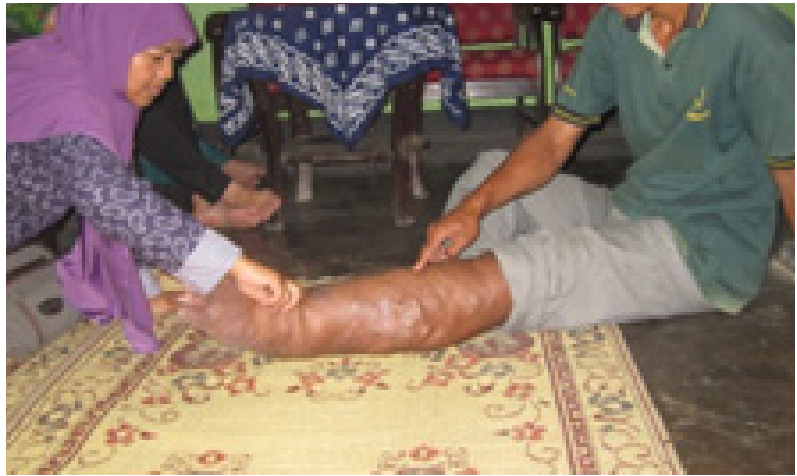

Gambar 2. Pembengkakan tungkai bawah kiri pada penderita elefantiasis di Dusun Cawan, Argodadi, Sedayu, Bantul, DIY

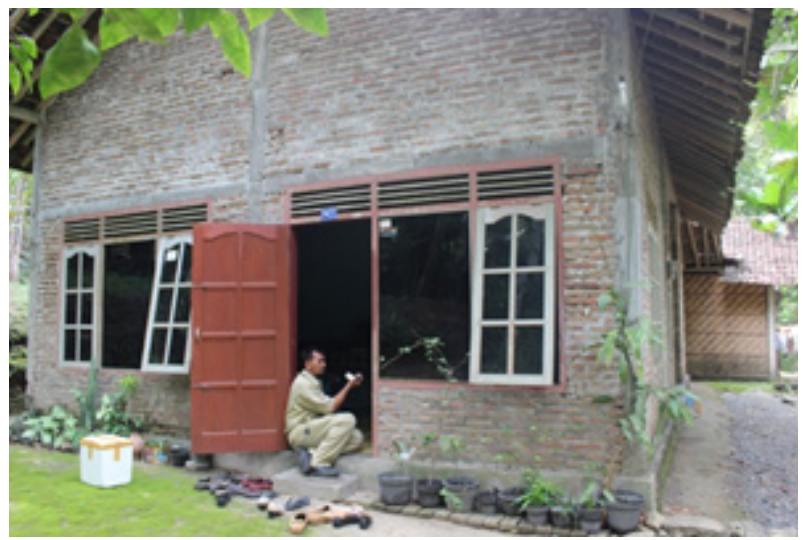

Gambar 3 (b). Tempat tinggal penderita filariasis di Dusun Depok, Gilangharjo, Pandak, Bantul, DIY.

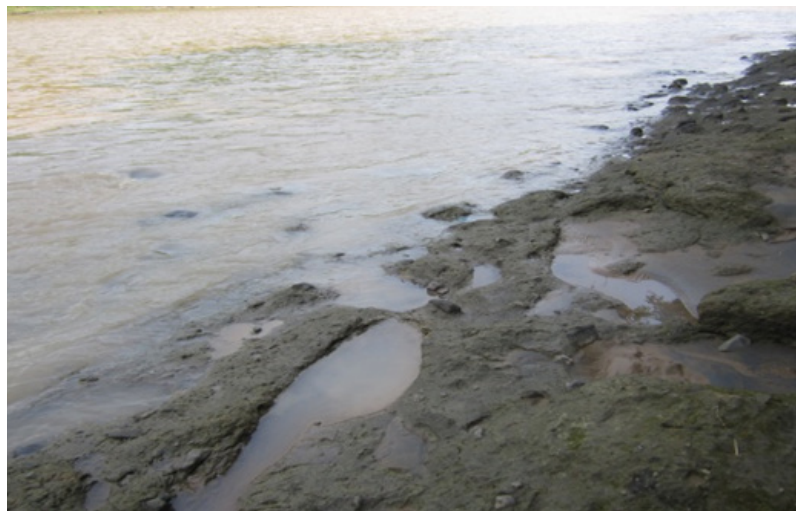

Gambar 5. Cerukan tempat perindukan nyamuk Anopheles sp di tepi sungai Progo

menjadi perindukan (breeding place) nyamuk vektor cacing filaria (Gambar 3 a dan b). Dari hasil survei lingkungan di Dusun Cawan, diketahui bahwa tempat tinggal penderita elefantiasis di tepi Sungai 


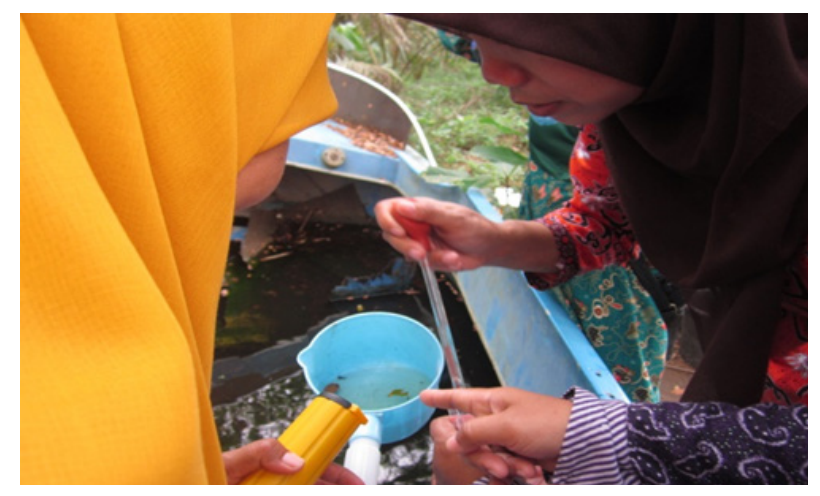

Gambar 6. Koleksi larva nyamuk dari bangkai kapal yang berada di tepi sungai Sungai Progo di Dusun Cawan, Argodadi, Sedayu Bantul, DIY

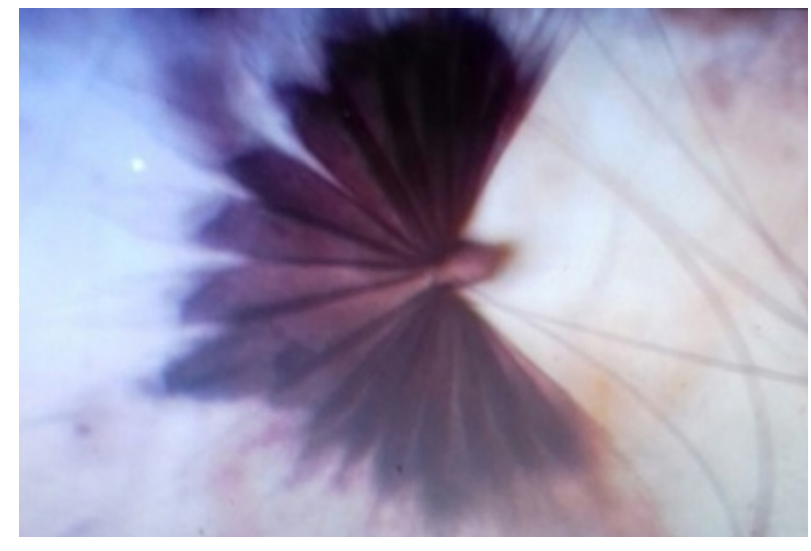

(a)

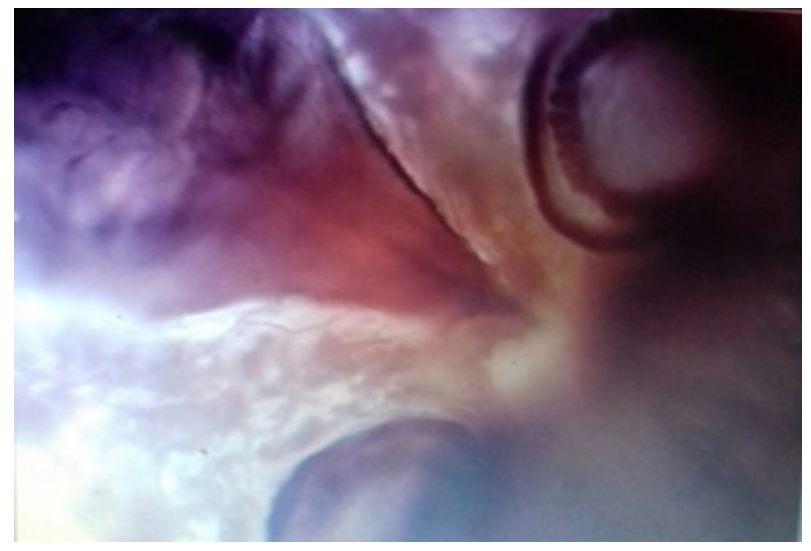

(b)

Gambar 7 (a,b). Larva nyamuk Anopheles vagus yang berasal dari dari bangkai kapal yang berada di tepi Sungai Progo di Dusun Cawan, Argodadi, Sedayu Bantul, DIY

Progo (Gambar 5). Di sekitar rumah penderita terdapat pekarangan kosong yang ditumbuhi semak belukar (Gambar 4). Menurut petugas Dinas Kesehatan Bantul, sudah pernah dilakukan survei nyamuk di daerah tersebut dan didapatkan nyamuk Anopheles sp.

Dari survei di lingkungan tempat tinggal penderita, tidak ditemukan larva nyamukAnopheles $s p$. Hal ini disebabkan survei dilakukan setelah terjadi hujan lebat pada malam sebelumnya, sehingga kemungkinan larva yang terdapat dalam lubang-lubang hanyut terbawa oleh air. Air sungai juga dalam keadaan meluap. Survei larva nyamuk di tempat-tempat genangan air dan sumur-sumur yang berada di sekitar tempat tinggal penderita juga hasilnya negatif (tidak ditemukan larva nyamuk).
Dari informasi penduduk yang berada di sekitar sungai, didapatkan data bahwa di bangkai kapal yang berada di tepi sungai banyak terdapat jentik-jentik nyamuk. Setelah diperiksa, pernyataan tersebut benar. Pada bangkai kapal yang digenangi air didapatkan larva nyamuk dalam jumlah yang sangat banyak. Larva nyamuk diambil dan dibawa ke Laboratorium Parasitologi, FK-KMK, UGM untuk diidentifikasi (Gambar 6).

\subsection{Identifikasi larva nyamuk}

Hasil identifikasi menunjukkan bahwa larva nyamuk dari Dusun Cawan, Argodadi, Sedayu Bantul, DIY adalah larva nyamuk Anopheles vagus (Gambar 7). Pada gambar 7a terlihat sikat palmata yang spesifik dan pada gambar $7 \mathrm{~b}$ terlihat adanya spirakel pada larva nyamuk Anopheles vagus. Larva nyamuk 


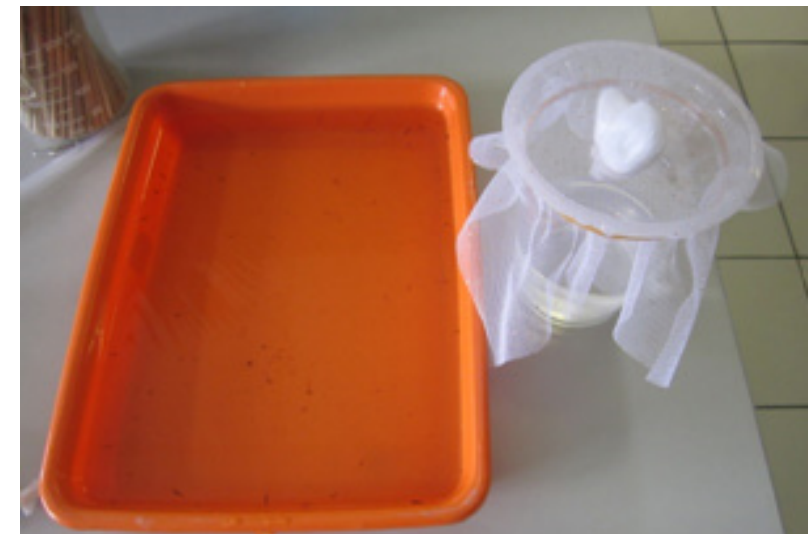

Gambar 8. Larva nyamuk Anopheles vagus dari bangkai kapal yang berada di tepi sungai Progo di Dusun Cawan, Argodadi, Sedayu Bantul, DIY dikolonisasi di Laboratorium Entomologi Departemen Parasitologi, FKKMK, UGM

lalu dipelihara di Laboratorium Entomologi, Departemen Parasitologi, FK-KMK, UGM sampai menjadi nyamuk dewasa untuk kepentingan pendidikan dan penelitian (Gambar 8). Nyamuk Anopheles vagus di NTT sudah dikonfirmasi sebagai vektor filariasis, dan merupakan nyamuk yang menjadi tersangka sebagai vektor malaria di Kecamatan Kokap, Kabupaten Kulon Progo. ${ }^{16,17}$

\section{Pembahasan}

Dari 6 terduga penderita elefantiasis di Kabupaten Bantul, hanya 2 penderita teridentifikasi, yaitu 1 penderita di Kecamatan Pandak dan 1 penderita di Kecamatan Sedayu. Empat terduga penderita elefantiasis lainnya tidak ditemukan alamatnya. Hasil uji darah yang digunakan untuk memastikan keberadaan mikrofilaria dari kedua penderita tersebut negatif. Hal ini mungkin dikarenakan cacing dewasanya sudah mati sehingga tidak memproduksi mikrofilaria lagi atau mungkin elefantiasis tersebut bukan diakibatkan oleh infeksi cacing filaria.

Berdasarkan penyebabnya, elefantiasis digolongkan menjadi dua, yaitu elefantiasis filaria dan elefantiasis nonfilaria. Elefantiasis filaria disebabkan oleh infeksi cacing filaria limfatik. Oleh karena itu, disebut juga filariasis limfatik (penyakit kaki gajah) yang merupakan penyakit menular menahun yang disebabkan oleh cacing filaria ( $W$. Bancroft, B. malayii, dan B. timori) dan ditularkan oleh nyamuk Mansonia sp., Anopheles sp., Culex $s p$. , dan Armigeres sp. ${ }^{11}$ Nyamuk-nyamuk tersebut memerlukan tempat perindukan (breeding place) yang berbeda-beda. Tempat perindukan nyamuk Mansonia sp., biasanya di rawa-rawa yang banyak tanaman airnya. Nyamuk Anopheles sp. bisa hidup di persawahan, di lubang pinggir-pingir sungai, hutan, dan sebagainya. Nyamuk Culex sp. lebih suka berkembang biak di air kotor seperti got dan sebagainya.

Elefantiasis nonfilaria antara lain disebabkan oleh podoconiosis, lepra, tuberkulosis, dan infeksi chlamydia. ${ }^{18-21}$ Tuberkulosis dan chlamydia biasanya menyebabkan elefantiasis genital. Podoconiosis adalah suatu penyakit yang disebabkan oleh adanya partikel silikon, aluminum, dan partikelpartikel logam lain yang berasal dari tanah dan berada dalam makrofag dan melekat pada limfosit. Elefantiasis pada podoconiosis dapat dicegah dengan beberapa tindakan, seperti membersihkan telapak kaki dari debu-debu vulkanik dan selalu menggunakan alas kaki, dibalut, dan sebagainya. Elefantiasis yang disebabkan oleh podoconiosis dapat mengakibatkan pembesaran kaki dan tungkai bawah, tidak menular, bersifat lokal, dan secara klinis dibedakan dengan filariasis dalam arah perkembangan elefantiasis yang bersifat ascending dan umumnya bilateral. Endemisitas podoconiosis berhubungan dengan keadaan geokimia lingkungan sekitar serta kebiasaan tidak memakai alas kaki..

Berdasarkan hasil wawancara, pemeriksaan fisik, dan survei lingkungan, penderita elefantiasis yang berasal dari Dusun Depok, Kelurahan Gilangharjo, Kecamatan Pandak, Kabupaten Bantul, DIY diduga menderita elefantiasis yang diakibatkan oleh infeksi cacing filaria B. malayi yang terjadi pada saat penderita tinggal di daerah Lampung selama lebih kurang 6 tahun. Lampung merupakan daerah endemis filariasis $B$. malayi. Namun, karena setelah tinggal di dusun Depok tidak ada nyamuk yang dapat berperan sebagai vektor $B$. malayi maka tidak terjadi penularan pada keluarga maupun penduduk sekitarnya. Dari hasil pemeriksaan darah 
juga tidak ditemukan mikrofilaria. Hal ini mungkin terjadi karena cacing filaria dewasa sudah mati dan juga tidak terjadi infeksi baru. Di beberapa daerah endemis filariasis, transmisi parasit selalu terjadi. Ini diketahui dengan ditemukannya kasus filariasis klinis baru setiap tahun. ${ }^{11}$

Penderita elefantiasis yang berasal dari Dusun Cawan, Argodadi, Sedayu, Bantul, DIY diduga menderita elefantiasis yang diakibatkan oleh podoconiosis. Hal ini dapat dilihat pada kondisi pembesaran kaki dan tungkai bawah yang bersifat ascending (elefantiasis yang disebabkan filariasis bersifat descending). Endemisitas podoconiosis berhubungan dengan keadaan geokimia lingkungan sekitar serta kebiasaan tidak memakai alas kaki. Yogyakarta adalah daerah tropis yang dekat dengan gunung berapi yang masih aktif sehingga pada saat erupsi banyak partikel geokimia yang menyebar ke darah-daerah sekitarnya.

Di Indonesia diagnosis pasti filariasis adalah dengan menemukan mikrofilaria dalam darah secara mikroskopis. Ketepatan diagnosis berhubungan dengan keputusan terapi yang tepat bagi penderita. ${ }^{5}$ Pada kenyataannya, banyak kasus elefantiasis filaria yang sudah berjalan bertahun-tahun, dan dalam pemeriksaan darah sudah tidak ditemukan mikrofilaria. Untuk memastikan penyebab elefantiasis pada dua orang penderita tersebut, perlu dilakukan konfirmasi keberadaan cacing filaria di dalam tubuh penderita, yaitu dengan pemeriksaan diagnostik lain secara serologik dan molekuler.

\section{Kesimpulan}

Di wilayah kerja Dinas Kesehatan Kabupaten Bantul, ditemukan dua orang penderita elefantiasis. Seorang penderita tinggal di wilayah kerja Puskesmas Pandak 1 dan seorang lainnya tinggal di wilayah kerja Puskesmas Sedayu 2. Penderita yang berasal dari Dusun Depok, Gilangharjo, Pandak, Bantul, DIY diduga menderita elefantiasis yang diakibatkan oleh infeksi cacing filaria Brugia malayi yang terjadi pada saat penderita tinggal di daerah Lampung yang merupakan daerah endemis filaria malayi selama lebih kurang 6 tahun. Sedangkan penderita yang berasal dari Dusun Cawan, Argodadi, Sedayu, Bantul, DIY diduga menderita elefantiasis yang diakibatkan oleh podoconiosis. Pada saat ini tidak ada potensi penularan filariasis di wilayah kerja Puskesmas Pandak 1 dan di wilayah kerja Puskesmas Sedayu 2. Di sepanjang tepi Sungai Progo di Dusun Cawan, Argodadi, Sedayu, Bantul, DIY banyak ditemukan tempat perindukan nyamuk Anopheles vagus.

Kami menyarankan untuk memastikan riwayat kesehatan 2 orang penderita elefantiasis tersebut. Perlu dilakukan pemeriksaan antibodi monoklonal anti Wuhereria bancrofti atau pemeriksaan antigen Brugia malayi pada penderita elefantiasis tersebut untuk memastikan apakah mereka pernah terinfeksi cacing filaria.

\section{Ucapan terima kasih}

Penulis mengucapkan terima kasih yang sebesarbesarnya kepada FKKMK, UGM yang telah memberikan bantuan Dana Masyarakat untuk Pengabdian Masyarakat tahun 2016 dan fasilitasfasilitas lainnya untuk terselenggaranya kegiatan ini. Ucapan terima kasih juga ditujukan kepada seluruh staf Dinas Kesehatan Kabupaten Bantul dan laboran Departemen Parasitologi, FKKMK, UGM yang telah membantu terlaksananya kegiatan ini.

\section{Konflik kepentingan}

Penulis menyatakan tidak ada konflik kepentingan dalam penelitian ini.

\section{Daftar pustaka}

1. World Health Organization. Global programme to eliminate lymphatic filariasis: Progress report on mass drug administration 2011. Wkly Epidemiol Rec. 2012;87(2) Suppl: 345-56.

2. Oemijati S. Current status of filariasis in Indonesia. Southeast Asian J Trop Med Publ HIth. 1993;24:2-4.

3. Kementerian Kesehatan Republik Indonesia. Profil pemberantasan penyakit menular dan penyehatan lingkungan (PPM\&PL) tahun 2014. 
Jakarta: Kementerian Kesehatan Republik Indonesia; 2015.

4. Partono F. The spectrum of disease in lymphatic filariasis. Ciba Found Symp. 1987;127:15-31.

5. Wahyuno TYM, Purwantyastuti, Supali T. Filariasis di Indonesia. Buletin Jendela Epidemiologi. 2010;1:28.

6. Kementerian Kesehatan Republik Indonesia. Situasi filariasis di Indonesia tahun 2015. Jakarta: Kementerian Kesehatan Republik Indonesia; 2016.

7. Fox LM, King CL. Lymphatic filariasis. In: Magill AJ, Hill DR, Solomon T, Ryan ET, editors. Hunter's tropical medicine and emerging infectious diseases. $9^{\text {th }}$ ed. USA: Saunders Elsevier Press; 2013. p. 816-22.

8. Becker N, Petric D, Zgomba M, Boase C, Madon M, Dahl C, et al. Mosquitoes and their control. $2^{\text {nd }}$ ed. Jerman: Springer; 2010.

9. Shabu S, Nutman TB. Lymphatic filariasis. In: Abhay R, Satoskar GL, Simon PJ, Hotez, Tsuji M. Medical Parasitology. Austin Texas, USA: Landes Bioscience; 2009. p. 76-84.

10. World Health Organization. Lymphatic filariasis practical entomology. Adv Parasitol. 2010;72:205-33.

11. Kementerian Kesehatan Republik Indonesia. Rencana nasional program akselerasi eliminasi filariasis di Indonesia. Jakarta: Subdit Filariasis \& Schistomiasis Direktorat P2B2; 2010.

12. Goel TC, Goel A. Lymphatic filariasis. Springer; 2008.

13. World Health Organization. Global programme to eliminate lymphatic filariasis: Progress report 2000-2009 and strategic plan 20102020. World Health Organization; 2010.

14. Stojanovich CJ, Scoot HG. Illustrated key to mosquitoes of Vietnam. Atlanta, Georgia: U. Department of Health, Education, and Welfare
Public Health Service; 1966

15. Pemerintah Kabupaten Bantul. Profil Kabupaten Bantul [Internet]. Bantul, DIY: Pemerintah Kabupaten Bantul; 2018 [cited 2018 Nov 29]. Available from: https://bantulkab.go.id/profil/ sekilas kabupaten bantul.html

16. Lobo V, Laumalay HM, Mapada MA. Tabel kehidupan Anopheles vagus sebagai vektor filariasis dan tersangka vektor malaria di Provinsi NTT. Loka Litbang P2B2 Waikabubak; 2016.

17. Wigati RA, Mardiana, Mujiyono, Alfiah S. Deteksi protein circumsporozoite pada spesies nyamuk Anopheles vagus tersangka vektor malaria di Kecamatan Kokap, Kabupaten Kulon Progo dengan uji enzyme-linked immunosorbent assay (ELISA). MPK. 2010;20(3):118-23.

18. Price EW. The Pathology of Non-Filarial Elephantiasis of the Lower Legs. Trans $R$ Soc Trop Med Hyg.1972;66(1):150-9.

19. Chintamani SJ, Tandon M, Khandelwal R, Aeron T, Jain S, Narayan N, et al . Vulval elephantiasis as a result of tubercular lymphadenitis: Two case reports and a review of the literature. J Med Case Rep. 2010;4(1):369.

20. ArakeriSU,SinkarP.Anunusualgrossappearance of vulval tuberculosis masquerading as tumor. Case Rep Obstet Gynecol. 2014;81540.

21. Nelson RA, Alberts GL, King Jr LE. Penile and scrotal elephantiasis caused by indolent Chlamydia trachomatis infection. Urology. 2003;61(1):224.

22. Price E. Endemic elephantiasis of the lower legs-natural history and clinical study. Trans R Soc Trop Med Hyg. 1974;68(1):44-52.

23. Davey G, Tekola F, Newport MJ. Podoconiosis: Non-infectious geochemical elephantiasis. Trans R Soc Trop Med Hyg.2007;101(12):117580. 